\title{
Variation in Chemicals and Growth Parameters of Taşköprü Garlic
}

\author{
Nezahat Turfan',a,* \\ ${ }^{1}$ Department of Biology, Faculty of Arts and Sciences, Kastamonu University, 37150 Kastamonu, Turkey \\ ${ }^{*}$ Corresponding author
}

A R T I C L E I N F
Research Article
Received : 17/09/2019
Accepted : 22/12/2019

\section{Keywords:}

Bulb

Cloves

Garlic

Growth

Nutrients

\begin{abstract}
A B S T R A C T
Main goals of the present study were (1) to initially investigate the nutrient contents and bioactive compounds in the bulb and cloves of garlic, and (2) to study the growth parameter after planting. Garlic bulbs were firstly separated into three categories as pickled, big and small, while the big garlic cloves were also classified into three categories as big, small and central. Secondly, the garlic samples were analyzed before planting for their element profile, proline, soluble protein, free amino acid, $\beta$-carotene, lycopene, total phenolic, soluble sugars, SOD and $\alpha$-amylase activities. Finally, the growth parameters were measured using the cultivated cloves and the pickled bulbs. According to the result, the highest soluble protein, $\mathrm{N}$, phenolic, lycopene and $\alpha$ amylase activity $(97.06 \mathrm{mg}$, $2.58 \%, 971 \mathrm{mg}, 0.368 \mathrm{mg}$ and $38.13 \mathrm{EU}$, respectively) were recorded in the biggest cloves. The highest proline, amino acid, glucose content $(93.84 \mu \mathrm{mol}, 23.54 \mathrm{mg}, 230.89 \mathrm{mg}$, respectively) and K, P, S, Mg, Mn, Fe and Zn (21940 ppm, 7577 ppm, 12200 ppm, 504 ppm, 38.1ppm, 377,7ppm and $44.5 \mathrm{ppm}$, respectively) were found in the pickled bulb. The maximum level of $\beta$-carotene $(0.282$ $\mathrm{mg}), \mathrm{Ca}, \mathrm{Cl}$ and $\mathrm{Sr}(11260 \mathrm{ppm}, 818.7 \mathrm{ppm}$ and $47.9 \mathrm{ppm})$ were determined in the small bulbs. Based on the growth parameters of seedlings, the highest value of shoot and root length $(39.12 \mathrm{~cm}$ and $24.11 \mathrm{~cm}$ respectively), the fresh weight of shoot and root (5.29 $\mathrm{g}$ and $4.54 \mathrm{~g}$ respectively) and dry weight of shoot and root ( $1.70 \mathrm{~g}$ and $1.24 \mathrm{~g}$ respectively) were noted with the big cloves. The results of the current study have indicated that the pickled cloves have higher macro and micro nutrients, proline, amino acid and glucose, while the big cloves of garlic have higher proline, phenolic, $\mathrm{N} \%$, lycopene and amylase activity. It can be said that the big cloves showed good value for the five bioactive compounds, but the pickled exhibited good value for the macro and micro element and glucose.
\end{abstract}

\section{Introduction}

Garlic (Allium sativum L.) contains many bioactive substances, mainly organ osulphur derivatives (allicin, alliin and allyl sulfides), flavonoids and isoflavonoids. In addition, garlic is very rich in various compounds such as carbohydrates, nitrogenous compounds, minerals (especially $\mathrm{K}, \mathrm{P}$ and $\mathrm{Se}$ ), vitamins, polyphenols and carotenoids (Chung, 2006; Asdaq and Inamdar, 2010). It has been consumed in the kitchen as raw and cooked because of its high nutrient value throughout the world (Azzini et al., 2014). However, it has been used in the treatment and preventing of several diseases for many years due to its high antioxidant capacity (Qidwai and Ashfaq, 2013). Garlic can be propagated vegetatively by sowing the cloves as well as sexual. Vegetative reproduction is preferred for cultivation purposes because it does not produce true seed. Therefore, researchers have reported that the genetic multiplication level is very low in vegetative grown garlic (Jenderek and Zewdie, 2005). The growth period of garlic include clove sprouting, shoot growth, bulb growth and maturation. The mature, dry garlic bulb is a storage structure particularly well adapted to vegetative reproduction. There are some 10 to 20 cloves in average bulb as big, small and central teeth. Some authors have stated that the larger outer cloves produce the best garlic, higher emergence, heavier clove and bulb with larger clove (Kotagariwar et al., 1997; Nasir et al, 2017). And also, the larger and heavy cloves are able to more uniform bulbs than smaller and light types (Del Pozo and González, 2005). Growth and development, bulb quality, nutrient value and clove sprouting and decaying of garlic have been reported to be associated with environmental conditions as well as clove size (Bhandari et al., 2012). Several workers have reported that techniques applied during growth and development in field, pre- and post- 
harvest conditions, bulb/clove type and size may affect yield quantity and quality of bulbs or cloves as colour, taste, favour, weight, sprouting, decaying as a result of increased respiration (Castellanos et al., 2004; Hughes et al., 2006). Hence, there is a great requirement to standardize the size of garlic cloves used for storage time and cultivation bulbs in order to increase effective garlic production. And well-defined healthy clove will contribute to increase quality, yield and extending of shelf life. Taşköprü garlic is the most widely grown garlic clone in Turkey due to its high soluble solid content, strong flavour, and long storage capability without the necessity of cold, and known as white gold, is unique to the district with its smell and taste (Ipek et al., 2008). Several studies have shown the differences in chemical composition, nutritional value and importance of Taşköprü garlic (Hacıseferoğulları et al., 2005; Turfan et al., 2016). There are many investigations on the antioxidant and antimicrobial effects, chemical compounds, and nutritional value of Taşköprü garlic depends on environmental factors, but limited studies were made about bulb size and clove types. Therefore, main aim of this current study was to investigate the effects of bulb size and clove types on mineral content, nitrogenous compound as proline, amino acid, soluble protein, beta carotene, soluble carbohydrates as sucrose, glucose and total soluble carbohydrate and also secondary metabolites as flavones and total phenolic in Taşköpü garlic.

\section{Material and Methods}

\section{Sample Preparation}

Garlic samples were taken from the local producers and were firstly classified into three categories as big, small and pickled. Secondly, the big garlic samples were separated into the cloves as big, small and central. Fresh weight, length and width of all garlic categories were noted. All measurements were carried out 15 times.

\section{Growth Experiment of the Garlic Samples}

The separated cloves as big, small and center and pickled bulbs were planted in some pots filled with mixture of peat and sand (1:1 rate). The big cloves and the pickled bulb were sown in the pots with a spacing of $4 \times 4.5 \mathrm{~cm}^{2}$ accommodating 10 cloves per pot, while the small and the centre cloves were sown in the pots with a spacing of $3 \times 4$ $\mathrm{cm}^{2}$ accommodating 15 cloves in each pot. The larger cloves and pickled bulbs were planted at $2 \mathrm{~cm}$ soil depth, while the small and centre cloves were dibbled at $1 \mathrm{~cm}$ soil depth. All samples were planted into soil mixture so that the ends of the cloves and bulbs were visible on the soil surface (Vural et al., 2000). The planting of the samples was completely performed using randomized design (CRD) with three replications. The planted pots were placed in a garden. All samples were irrigated according to soil capacity at 3 to 5 days' interval. Germination of the galic samples was measured as success of garlic tip appearance above soil surface. Seedlings were collected at 28 days after emergence of new leaves from the cloves. The seedlings were cleaned from the soil and washed with tap water and rinsed with distilled water. The seedlings were taken on dehydrated paper and the root and plant height and root and shoot length and dry weights were 848 determined. Measurements of fresh weight, dry weight, length of shoot and root in seedlings were carried out with seven weeks old plant. The length of the seedling was estimated as cm by measuring the area of the seedling from the root throat to the growth tip with a millimetre ruler, while the root length was determined by measuring the distance from the root throat to the end of the root. The fresh weight was weighed with digital scales with the accuracy of $\pm 0.01 \mathrm{~g}$ of the above and below ground parts of the seedlings. Dry weight was measured by weighing the subsoil and subsoil sections at a temperature of $65^{\circ} \mathrm{C}$ for 24 hours with a digital scale.

\section{Chemical Analysis}

All samples were then dried in an oven at $60^{\circ} \mathrm{C}$ for 48 hours. The dried samples were powdered under the laboratory conditions and used in chemical analysis. Total soluble protein contents of garlic samples were analysed according to the method of Bradford (1976) using the BioRadR assay kit with bovine serum albumin as a calibration standard. For free amino acid content, the garlic samples $(0.5 \mathrm{~g})$ were boiled in $10 \mathrm{ml}$ of $80 \%$ ethanol. The extract obtained was centrifuged at $800 \mathrm{~g}$ for $15 \mathrm{~min}$. The supernatant was completed to $10 \mathrm{ml}$ with $80 \%$ ethanol. Then, $1 \mathrm{ml}$ of extract was transferred into test tube $(25 \mathrm{ml})$ and $0.1 \mathrm{~N} \mathrm{NaOH}$ was added using methyl red. A $1 \mathrm{ml}$ of ninhydrin reagent was added and the mixture was boiled for $20 \mathrm{~min}$. Afterwards, $5 \mathrm{ml}$ of ninhydrin reagent was added and it was cooled. The mixture was completed to 25 $\mathrm{ml}$ with distilled water. The standard was prepared by glycine and the absorbance was read at $570 \mathrm{~nm}$ (Moore and Stein, 1948). The amount of proline was determined by the method of Bates et al. (1973). Total phenolic content (TPC) was determined using the Folin-Ciocalteu assay (Singleton et al., 1999). $1 \mathrm{~g}$ of the samples were diluted to $1 \mathrm{ml}$ with methanol and extracted. A $2.5 \mathrm{ml}$ Folin-Ciocalteu reagent $(10 \%)$ was added to extract $(0.5 \mathrm{ml})$ and mixed. Following, $2.5 \mathrm{ml}$ of $7.5 \%$ saturated sodium carbonate solution was put into this mixture. The mixture was incubated at $45^{\circ} \mathrm{C}$ for $45 \mathrm{~min}$ in the dark and formation of blue colour of samples were observed. At the end of, absorbance of blue colour in the samples was measured at $765 \mathrm{~nm}$. For total phenolic analysis, a calibration curve was obtained by using 5 different concentrations of gallic acid ranged from 0.007813 to $0.125 \mathrm{mg} \mathrm{ml}^{-1}$ as standard $\left(\mathrm{R}^{2}=0.9993\right)$.

The total phenolic content was calculated using regression equation of the curve obtained and the results were expressed as mg of gallic acid equivalents per $g$ of dry samples. The $\alpha$-amylase activity in the samples was measured according to Bernfeld (1955) method by 3,5dinitro salicylic acid colour indicator and starch substrate of $1 \%$, spectrophotometry at $540 \mathrm{~nm}$. Determination of the total soluble carbohydrate was performed according to the Antron Method by spectrophotometry at $620 \mathrm{~nm}$ (McCready et al., 1950). Sucrose and glucose content was estimated according to the Antron Method by spectrophotometry at $620 \mathrm{~nm}$ for sucrose and at $630 \mathrm{~nm}$ for glucose (Handel, 1968). Bernfeld, P. (1955) Amylases, alpha and beta. Methods in enzymology I: 149-158.

For enzyme activity, nearly 0.5 -gram sample was homogenized with $50 \mathrm{mM}(\mathrm{pH}$ 7.6) phosphate buffer solution $(10 \mathrm{~mL})$ ground in liquid nitrogen and containing $0.1 \mathrm{mM}$ Na-EDTA. The homogenized samples were 
centrifuged for $15 \mathrm{~min}$ at $15000 \mathrm{~g}$ and $+4^{\circ} \mathrm{C}$, and then the enzyme activities in the resulting supernatant were determined according to the methods of Cakmak (1994). Superoxide dismutase (SOD) activities were measured according to the methods under nitro blue tetrazolium chloride (NBT) light by $\mathrm{O}_{2}^{-}$reduction. $\beta$ carotene and lycopene content of the garlic samples were determined using methods given in Nagata and Yamashita (1992). Garlic samples were extracted with acetone-hexane (4:6) at once, then optical density of the supernatant at 663 $\mathrm{nm}, 645 \mathrm{~nm}, 505 \mathrm{~nm}$ and $453 \mathrm{~nm}$ were measured by spectrophotometer at the same time. The concentration of $\beta$-carotene $(\beta \mathrm{c})$ and lycopene $(\mathrm{L})$ in garlic sample extracts (in $\mathrm{mg}$ per $100 \mathrm{ml}$ ) were estimated spectrophotometrically using the following equations:

$\beta c=0.216 \times A 663-1.22 \times \mathrm{A} 645-0.304 \times \mathrm{A} 505+0.452 \times \mathrm{A} 453(1)$

$\mathrm{L}=-0.0458 \times \mathrm{A} 663+0.204 \times \mathrm{A} 645+0.372 \times \mathrm{A} 505-0.0806 \times \mathrm{A} 453(2)$

\section{Mineral Element Contents}

The elemental analysis was performed by using energy dispersive X-ray fluorescence spectrometry (Spectro, Xepos, Ametek, Germany) (Carvalho et al., 2005). $2.0 \mathrm{~g}$ dried garlic samples were digested in solution of $\mathrm{HNO}_{3}$. The solutions obtained after digestion were used for direct spectrophotometric analysis. Calibration was done using metal/mineral standard solutions. Content of the elements was expressed as $\mathrm{mg} \mathrm{kg}^{-1}$ dry weight.

\section{Statistical Analysis}

Analysis of variance (ANOVA) was applied for analysing the differences in the chemical composition of Taşköprü garlic samples using the SPSS program ver. 11.0 for Windows. Following the results of ANOVAs, Tukey's honestly significance difference (HSD) test $(\alpha=0.05)$ was used for testing differences between group means.

\section{Results and Discussions}

Variation in germination rates and growth parameter as fresh and dry weight and length of the shoot and root were measured in fully ripe seedling, and result are given in Table 1. According to the results, a significant difference was observed between all parameters $(\mathrm{P}<0.05)$.

As seen in the Table 1, mean fresh weight of garlic bulbs ranged from $6.14 \mathrm{~g}$ to $32.07 \mathrm{~g}$ in bulb, while mean weight of the big garlic cloves ranged from $1.53 \mathrm{~g}$ to 3.83 g. The big garlic bulbs had the highest length $(3.36 \mathrm{~cm})$ and width $(4 \mathrm{~cm})$, while the pickled garlic bulbs had the lowest $(2.78 \mathrm{~cm}$ and $2.35 \mathrm{~cm}$, respectively). As for the cloves, mean length of the cloves ranged from $3.23 \mathrm{~cm}$ for the big cloves to $1.65 \mathrm{~cm}$ for the centre cloves, while mean width of the cloves ranged from $2.18 \mathrm{~cm}$ for the big cloves to 0.81 $\mathrm{cm}$ for the centre cloves. As shown in Table 1, the highest germination was obtained with the big clove as $96.67 \%$, and the lowest germination was obtained with $75.56 \%$ with the central cloves (Table 1). On the other hand, the highest shoot and root length, fresh weight of shot and root, and dry weight of shoot and root was obtained with the big cloves, while the lowest values of them was noted with the small and the centre cloves. The second highest values in seedlings were from the seedling originated from the pickled bulb (Table 1). Our findings regarding shoot/root length and weight were coincided with the results of similar studies. Kotagariwar et al. (1997), Castellanos et al. (2004) and Nasir et al. (2017) have stated that clove size is effective in the vegetative growth and development. The largest cloves or bulbs contain more reserve nutrients and induce growth rate in initial stage of the development.

Table 1. Mean fresh weight, length and width; length of shoot and root, fresh and ry weight of shoot and root; and emergence rate of garlic bulbs and cloves.

\begin{tabular}{|c|c|c|c|c|c|c|}
\hline & Size & $\begin{array}{c}\text { Fresh weight } \\
(\mathrm{g})\end{array}$ & $\begin{array}{l}\text { Length } \\
(\mathrm{cm})\end{array}$ & $\begin{array}{l}\text { Width } \\
(\mathrm{cm})\end{array}$ & $\begin{array}{c}\text { Emergence rate } \\
(\%)\end{array}$ & $\begin{array}{l}\text { Shoot length } \\
(\mathrm{cm})\end{array}$ \\
\hline \multirow{3}{*}{ Clove } & Big & $3.83^{\mathrm{c}} \pm 0.14$ & $3.23^{\mathrm{c}} \pm 0.09$ & $2.18^{\mathrm{c}} \pm 0.10$ & $96.67^{\mathrm{c}} \pm 0,34$ & $39.12^{\mathrm{d}_{ \pm}}$ \\
\hline & Small & $2.31^{\mathrm{b}} \pm 0.12$ & $2.88^{\mathrm{b}} \pm 0.10$ & $1.36^{\mathrm{b}} \pm 0.04$ & $82.22^{b} \pm 0.22$ & $21.41^{\mathrm{a}} \pm 0.76$ \\
\hline & Centre & $1.53^{\mathrm{a}} \pm 0.05$ & $1.65^{\mathrm{a}} \pm 0.08$ & $0.81^{\mathrm{a}} \pm 0.04$ & $75.56^{\mathrm{a}} \pm 0.22$ & $26.11^{\mathrm{b}} \pm 0.66$ \\
\hline \multirow{3}{*}{ Bulb } & Pickled & $6.14^{\mathrm{d}} \pm 0.37$ & $2.78 \mathrm{~b} \pm 0.08$ & $2.35^{\mathrm{c}} \pm 0.08$ & $80^{\mathrm{b}} \pm 0.37$ & $29.62^{c} \pm 0.64$ \\
\hline & Big & $32.07^{\mathrm{f}} \pm 0.09$ & $3.36^{\mathrm{c}} \pm 0.04$ & $4.00_{\mathrm{d}} \pm 0.04$ & - & - \\
\hline & Small & $16.30^{\mathrm{e}} \pm 0.37$ & $2.91^{\mathrm{b}} \pm 0.08$ & $3.98^{\mathrm{d}} \pm 0.09$ & - & - \\
\hline \multirow{2}{*}{\multicolumn{2}{|c|}{$\begin{array}{l}\text { F } \\
\text { Sig. }\end{array}$}} & 625.04 & 59.34 & 249.94 & 8.45 & 12.80 \\
\hline & & 0.000 & 0.000 & 0.000 & 0.007 & 0.000 \\
\hline \multicolumn{2}{|r|}{ Size } & $\begin{array}{l}\text { Root length } \\
\text { (cm) }\end{array}$ & $\begin{array}{l}\text { Shoot fresh } \\
\text { weight }(\mathrm{g})\end{array}$ & $\begin{array}{l}\text { Shoot dry } \\
\text { weight }(\mathrm{g})\end{array}$ & $\begin{array}{l}\text { Root fresh } \\
\text { weight }(\mathrm{g})\end{array}$ & $\begin{array}{l}\text { Root dry Weight } \\
\text { (g) }\end{array}$ \\
\hline \multirow{3}{*}{ Clove } & Big & $24.11^{\mathrm{d}_{ \pm}} 0.78$ & $5.29^{\mathrm{d}} \pm 0.36$ & $4.54^{\mathrm{d}} \pm 0.23$ & $1.70^{\mathrm{c}} \pm 0.11$ & $1.24^{\mathrm{d}} \pm 0.23$ \\
\hline & Small & $15.51^{\mathrm{b}} \pm 0.89$ & $1.26^{\mathrm{b}} \pm 0.21$ & $1.01^{\mathrm{a}} \pm 0.11$ & $0.34^{\mathrm{a}} \pm 0.09$ & $0.11^{\mathrm{a}} \pm 0.02$ \\
\hline & Centre & $15.32^{\mathrm{a}} \pm 1.35$ & $0.83^{\mathrm{a}} \pm 0.18$ & $1.19^{\mathrm{b}} \pm 0.24$ & $0.21^{\mathrm{a}} \pm 0.06$ & $0.26^{\mathrm{b}} \pm 0.08$ \\
\hline \multirow{3}{*}{ Bulb } & Pickled & $19.31^{\mathrm{c}} \pm 1.33$ & $2.87^{\mathrm{c}} \pm 0.38$ & $2.07^{c} \pm 0.31$ & $1.23^{\mathrm{b}} \pm 0.21$ & $0.47^{\mathrm{c}} \pm 0.11$ \\
\hline & Big & - & - & - & - & - \\
\hline & Small & - & - & - & - & - \\
\hline \multirow{2}{*}{\multicolumn{2}{|c|}{$\begin{array}{l}\text { F } \\
\text { Sig. }\end{array}$}} & 13.67 & 47.83 & 49.53 & 30.91 & 14.23 \\
\hline & & 0.000 & 0.000 & 0.000 & 0.000 & 0.000 \\
\hline
\end{tabular}

${ }^{\mathrm{a}-\mathrm{f}}$ Mean values with different superscript symbols along the columns are significantly $(\mathrm{P}<0.05)$ different. 
The chemical composition of bulbs and cloves were measured in fully ripe Taşköprü garlics to determine the effect of clove and bulb size on proline, total soluble protein, total free amino acid, total nitrogen ( $\mathrm{N} \%), \alpha-$ amylase and SOD activities, total phenolic, c $\beta$-caroten, lycopene, glucose, sucrose, total soluble carbohydrate, total carbon $(\mathrm{C} \%)$ levels and mineral profile. According to the results, a significant difference was determined between the bulbs and the cloves $(\mathrm{P}<0.05)($ Table 2$)$.

Vegetables are an important component of the human diet and considered to be a high source of nitrogen compounds such as proline, free amino acid, soluble protein and antioxidant enzymes as superoxide dismutase (SOD), catalase (CAT), guaiacol peroxidase (GPOX) and play an important role during nutrition, growth and development of plants (Caverzan et al., 2012; Liu, 2013). Some leafy vegetables have higher nitrogen compound accounting for $72-94 \%$ of the total nitrogen intake of humans (Gilchrist et al., 2010; Jones, 2014). According to the results, the highest total soluble protein content, 97.96 $\mathrm{mg} / \mathrm{g}$ was determined in the big cloves, while the lowest total soluble protein content $(70.61 \mathrm{mg} / \mathrm{g})$ was noted in the big bulb samples (Table 2). As seen in Table 2, while the amount of proline ranged from 11.68 to $31.92 \mu \mathrm{mol} / \mathrm{g}$ in the cloves, it ranged from 29.38 to $93.84 \mu \mathrm{mol} / \mathrm{g}$ in the bulb samples. When we evaluated the total free amino acid of the bulbs and the cloves, the lowest amino acid level $(7.75$ $\mathrm{mg} / \mathrm{g}$ ) was obtained from the small size cloves; the highest amino acid was obtained from the pickling bulbs with $23.54 \mathrm{mg} / \mathrm{g}$ (Table 2). There were no significant differences in the total $\mathrm{N}(\%)$ level between the cloves and the bulbs, and mean $\mathrm{N}$ content ranged from $2.10 \%$ to $2.58 \%$ (Table 2). The results of protein were similar with the studies of many researchers. Petropoulos et al. (2018) found that the amount of protein ranged $4.62 \mathrm{~g} / 100 \mathrm{~g}$ to $7.45 \mathrm{~g} / 100 \mathrm{~g}$. Azoom et al. (2014) showed that the amount of soluble protein ranged from $1.37 \%$ and $3.78 \%$ in garlic genotypes. Khan et al. (2016) noted that garlic samples were rich in crude protein as $13.83 \%$.

When the activity of superoxide dismutase (SOD) enzyme was considered, it was seen that the highest activity as $147.49 \mathrm{EU} / \mathrm{mg}$ was obtained from the pickled bulb while the lowest activity as $49.38 \mathrm{EU} / \mathrm{mg}$ was in the small bulb (Table 2). SOD activity results are consistent with other studies, Martin et al. (2016); Stajner et al. (2004) found that Alliaceae member, especially Allium genus had high antioxidant activity. Turfan et al. (2016) showed that the SOD values of the garlic were $23.35 \mathrm{EU} / \mathrm{mg}$. Belhadj et al. (2015) investigated antioxidant and antimicrobial activities of Allium sativum L. leaves, bulbs and roots. Their result indicated that the highest SOD activity was highest level in garlic bulb (50 EU). However, leaf and roots had lower SOD activity (48 EU and $43 \mathrm{EU}$ ). In a study conducted by Alic1 and Arabac1 (2016), activity of SOD was found to be $11.6 \mathrm{EU}$ in Rumex obtusifolius L. Ran et al (2004) noted that, SOD activity was 21.02 EU in goose berry, 6.58 EU in grapes, $30.45 \mathrm{EU}$ in orange and 6.91 EU in tomato. Alves et al. (2008) and Krishnamurthy et al. (2010) have stated that antioxidant enzyme such as SOD, CAT, POD and GPOX are abundant in fruits and vegetables and they are effective protecting of several diseases. It was reported that rising the intake of antioxidant enzyme rich foods may have helped 850 overcoming free radicals related health problems due to stabilizing or deactivating free radicals with enzymes (Sudipta et al., 2014). Circu and Aw (2010) and Le Quere et al. (2014) showed that liposomal antioxidants containing SOD had at least 40 times more activity in the cell treatment within two hours than the others.

When the activity of $\alpha$-amylase activity was evaluated, it was seen that the amylase activity was influenced by the clove and bulb types. The highest activity of amylase was found with the big clove as $38.31 \mathrm{EU}$, but it was lowest with the small bulbs as 5.31 EU (Table 3). $\alpha$-amylase are the most important enzymes which break starch into metabolizable soluble sugars that used during the initial seedling growth and development as energy sources (Bernfeld, 1991; McCarty, 1995). The findings of germination and growth parameters confirmed this result in the present study. Germination rate, shoot and root length, fresh weight of shoot and root and dry weight shhot and root were higher as amylase activity was higher in the big cloves (Table 1 and 3). And also, when activity of enzyme was lowered the germinated rate and growth parameters were reduced in the central, small cloves and pickled bulbs (Table 1 and 3). The researchers have stated that amylase can degrade starch molecules into sugars as glucose, fructose and sucrose and after that germination they are mobilized to the embryonic axes (Gupta, 2003; Agić et al., 2009). Allium species are rich in sugars such as glucose, sucrose, fructose and fructo-oligosaccharides (Koruri et al., 2014). Several researchers have reported that sugars have an important role in plant and the amount of them may change depends on genetic, age, organs competitiveness and environmental factors (Ciereszko, 2018). Sugar profile of the garlic cloves and bulbs for this present study was given in Table 3 . Glucose level ranged from 180.38 to $230.89 \mathrm{mg} / \mathrm{g}$. The amount of sucrose was highest in the smaller cloves $(75.42 \mathrm{mg} / \mathrm{g})$, whereas it was lowest $(48.14 \mathrm{mg}$ ) in the central cloves (Table 3). Total soluble carbohydrate content of garlic segments varied between 82.63 and $100.33 \%$, while total carbon level (C\%) ranged from 37.55 to $43.55 \%$ (Table 3). Azoom et al. (2014) investigated total soluble sugar content in bulbs of eight varieties of onion, and found that total soluble sugar level ranged from 2.62 to $4.72 \%$. Lisciani et al. (2017) analysed the amount of sugar variation in the four commonly consumed "Italian local landraces" and their result showed that fructan contents were to be the most representative component in all the garlic samples, comprising about $78 \%$ of the total carbohydrates, and varying from 45.8 to $54.4 \mathrm{~g} / 100 \mathrm{~g}$. And also the amount of total sugars ranged between 2.12 and $3.27 \mathrm{~g} / 100 \mathrm{~g}$ with higher levels of sucrose.

Koruri et al. (2014) noted that the concentration (on dry weight basis) of inulin in natural prebiotic sources was $16.60 \%$ for garlic. Petropoulos et al. (2018) studied the chemical composition and quality (total soluble solids, dry matter content, nutritional value, mineral composition, organic acids, fatty acids content and free sugars content), and also bulb morphology of garlic. Their results showed that total soluble carbohydrate level of garlic genotypes changed between 23.13 and $36.03 \mathrm{~g} / 100 \mathrm{~g}$ and also protein level of them ranged from 4.62 to $7.45 \mathrm{~g} / 100 \mathrm{~g}$. Ritota et al. (2012) found that sucrose as the main carbohydrate in Italian garlics. Rekowska and Skupie'n (2009) observed 
that total carbohydrate of bulb ranged from 16.15 to $18.00 \%$, while it varied between 3.80 and $4.84 \%$ in green leaf sample. Khan et al. (2016) found that the amount of carbohydrates of garlic was $72.01 \%$.

$\beta$-carotene and lycopene are belonging to a group of pigments molecules called carotenoids, which are abundantly present in part of plant tissue like fruits, leaf, root and seeds. They are known to be very efficient physical and chemical quenchers of reactive oxygen species. They have important role protecting several diseases such as cancer, heart disease, macular degeneration and ageing, with their highly reactive conjugated bounds and antioxidant properties (Fiedor and Burda, 2014). It was reported that the recommended dose for $\beta$-carotene for adults was $700 \mu \mathrm{g}$ for females and $900 \mu \mathrm{g}$ for males. The common dose for lycopene supplements was 2 to $30 \mathrm{mg}$ daily (Story et al., 2010). In this present study, $\beta$ carotene level varied in garlic samples, the smaller bulb had the highest value $(0.282 \mathrm{mg} / \mathrm{g})$ compared to all samples, whereas the big clove had the lowest carotene $(0.164 \mathrm{mg} / \mathrm{g})$ (Table 2). As seen in the Table 1, the amount of lycopene was lowest $(0.271 \mathrm{mg})$ in the central clove and $0.279 \mathrm{mg}$ in the small bulb (Table 2). However, the big bulb and the big clove had the highest lycopene ( 0.382 and $0.368 \mathrm{mg} / \mathrm{g}$, respectively) (Table 2). Many researchers have stated that vegetables and fruits are a source of carotenoids. Chandra-Hioe et al. (2017) studied some vegetables in order to determine the range of $\beta$ - carotene and found that the amount of $\beta$-carotene ranged from 1974 to $6604 \mu \mathrm{g} / 100 \mathrm{~g}$. Hanson et al. (2011) showed that the carotenoids contents varied depended on cultivar, stage of maturity, analysed part of the plants, environmental conditions, treatments of preharvest and postharvest, storage conditions and time and also seasonally. For example, flowering cabbage collected in dry season had higher $\beta$ carotene $(96000 \mu \mathrm{g} / 100 \mathrm{~g})$ than those harvested in wet season. Tuan et al. (2011) showed that green leaf of garlic contained very high carotene $(73.44 \mathrm{~b} \mu \mathrm{g} / \mathrm{g})$, but it was significantly lower in the bulbs $(2.85 \mu \mathrm{g} / \mathrm{g})$. Azzini et al. (2014) found that $\beta$-carotene level ranged from 5.68 to $7.41 \mu \mathrm{g} / 100 \mathrm{~g}$ and 6.36 to $7.46 \mu \mathrm{g} / 100 \mathrm{~g}$ for two garlic variety bulbs.

Phenolic compounds synthesized by plants as secondary metabolites to function as a chemical defense against abiotic and biotic stress conditions (Kim et al., 2013; Beato et al., 2011). However, epidemiological studies have showed that high dietary intake of them is thought to be responsible for preventing of some chronic diseases (Rein et al., 2013; Sharma, 2014). Total phenolic content in the samples of garlic ranged from 7.06 to 9.1 $\mu \mathrm{g} / \mathrm{g}$. and the highest value was seen in the big clove. The lowest value of phenolic was found in the big size bulb (Table 2). Garlic has been shown by different studied to be rich in phenolic compounds.

Table 2. Variation in total soluble protein, proline, free amino acid, nitrogen (N\%), SOD activity and total phenolic content among different tissues of Taşköprü garlic.

\begin{tabular}{ll|llllll}
\hline \multicolumn{2}{c|}{ Size } & \multicolumn{1}{c}{ TSP } & \multicolumn{1}{c}{ P } & \multicolumn{1}{c}{ TFAC } & \multicolumn{1}{c}{ N\% } & SOD & TP \\
\hline \multirow{3}{*}{ Clove } & Big & $97.06^{\mathrm{f}} \pm 0.14$ & $15.70^{\mathrm{b}} \pm 0.07$ & $21.81^{\mathrm{d}} \pm 0.04$ & $2.58^{\mathrm{c}} \pm 0.041$ & $40.87^{\mathrm{a}} \pm 0.14$ & $9.71^{\mathrm{c}} \pm 0.14$ \\
& Small & $88.72^{\mathrm{d}} \pm 0.11$ & $31.92^{\mathrm{d}} \pm 0.11$ & $7.75^{\mathrm{a}} \pm 0.06$ & $2.44^{\mathrm{c}} \pm 0.006$ & $47.78^{\mathrm{b}} \pm 0.11$ & $8.88^{\mathrm{b}} \pm 0.11$ \\
& Central & $77.60^{\mathrm{b}} \pm 0.16$ & $11.78^{\mathrm{a}} \pm 0.14$ & $12.67^{\mathrm{b}} \pm 0.09$ & $2.10^{\mathrm{b}} \pm 0.010$ & $53.43^{\mathrm{c}} \pm 0.35$ & $7.76^{\mathrm{a}} \pm 0.16$ \\
\hline \multirow{3}{*}{ Bulb } & Pickled & $93.35^{\mathrm{e}} \pm 0.11$ & $93.84^{\mathrm{f}} \pm 0.11$ & $23.54^{\mathrm{e}} \pm 0.23$ & $2.19^{\mathrm{b}} \pm 0.010$ & $65.57^{\mathrm{e}} \pm 0.06$ & $9.34^{\mathrm{c}} \pm 0.11$ \\
& Big & $70.61^{\mathrm{a}} \pm 0.18$ & $29.38^{\mathrm{c}} \pm 0.15$ & $15.20^{\mathrm{c}} \pm 0.03$ & $2.52^{\mathrm{c}} \pm 0.008$ & $74.48^{\mathrm{f}} \pm 0.21$ & $7.06^{\mathrm{a}} \pm 0.18$ \\
& Small & $80.34^{\mathrm{c}} \pm 0.19$ & $59.69^{\mathrm{e}} \pm 0.26$ & $14.71^{\mathrm{c}} \pm 0.05$ & $1.96^{\mathrm{a}} \pm 0.068$ & $62.45^{\mathrm{d}} \pm 0.21$ & $8.04^{\mathrm{b}} \pm 0.19$ \\
\hline F & & 4691.75 & 43144.71 & 2986.76 & 56.85 & 10556.43 & 4691.75 \\
Sig & & 0.000 & 0.000 & 0.000 & 0.000 & 0.000 & 0.000 \\
\hline
\end{tabular}

TSP: Total soluble protein mg/g, P: Proline $\mu \mathrm{mol} / \mathrm{g}$, TFAC: Total free amino acid mg/g, SOD: SOD EU/mg protein, TP: Total phenolic $\mathrm{mg} / \mathrm{g}$, ${ }^{\text {a-f }} \mathrm{Mean}$ values with different superscript symbols along the columns are significantly $(\mathrm{P}<0.05)$ different.

Table 3 Variation in $\beta$-caroten, lycopen, $\alpha$-amylase activity, glucose, sucrose, total soluble carbohydrate, total C ( $\%)$ and $\mathrm{H}(\%)$ content among different tissues of Taşköprü garlic.

\begin{tabular}{|c|c|c|c|c|c|}
\hline \multicolumn{2}{|c|}{ Size } & $\beta$-caroten $\mathrm{mg} / \mathrm{g}$ & Lycopen $\mathrm{mg} / \mathrm{g}$ & $\alpha$-Amylase EU/mg protein & Glucose mg/g \\
\hline \multirow{3}{*}{ Clove } & Big & $0.164^{\mathrm{a}} \pm 0.001$ & $0.368^{\mathrm{d}} \pm 0.002$ & $38.31^{\mathrm{e}} \pm 0.16 \mathrm{e}$ & $190.26^{\mathrm{b}} \pm 0.11$ \\
\hline & Small & $0.218^{\mathrm{c}} \pm 0.003$ & $0.306^{\mathrm{c}} \pm 0.003$ & $13.87^{\mathrm{c}} \pm 0.20 \mathrm{c}$ & $224.35^{\mathrm{d}} \pm 0.17$ \\
\hline & Central & $0.226^{\mathrm{d}} \pm 0.002$ & $0.271^{\mathrm{a}} \pm 0.003$ & $7.70^{\mathrm{a}} \pm 0.10 \mathrm{~b}$ & $180.38^{\mathrm{a}} \pm 0.09$ \\
\hline \multirow{3}{*}{ Bulb } & Pickled & $0.213^{\mathrm{b}} \pm 0.002$ & $0.285^{\mathrm{c}} \pm 0.001$ & $8.86^{\mathrm{b}} \pm 0.07 \mathrm{~b}$ & $230.89^{f} \pm 0.20$ \\
\hline & Big & $0.217^{c} \pm 0.002$ & $0.382^{\mathrm{e}} \pm 0.004$ & $17.47^{\mathrm{d}} \pm 0.17 \mathrm{~d}$ & $212.77^{c} \pm 0.14$ \\
\hline & Small & $0.282^{\mathrm{e}_{1}} \pm 0.003$ & $0.279^{\mathrm{b}} \pm 0.002$ & $5.31 \pm 0.11 \mathrm{a}$ & $228.81^{\mathrm{e}} \pm 0.12$ \\
\hline \multirow{2}{*}{\multicolumn{2}{|c|}{$\begin{array}{l}\mathrm{F} \\
\mathrm{Sig}\end{array}$}} & 283.75 & 336.92 & 10556.43 & 22441.2 \\
\hline & & 0.000 & 0.000 & 0.000 & 0.000 \\
\hline \multicolumn{2}{|c|}{ Size } & Sucrose $\mathrm{mg} / \mathrm{g}$ & Total oluble carbohydrate (\%) & $\mathrm{C}(\%)$ & $\mathrm{H}(\%)$ \\
\hline \multirow{3}{*}{ Clove } & Big & $53.85^{\mathrm{b}} \pm 0.08$ & $87.63^{\mathrm{b}} \pm 0.0$ & $38.90^{\mathrm{b}} \pm 0.07$ & $6.49^{\mathrm{d}} \pm 0.02$ \\
\hline & Small & $75.42^{\mathrm{e}} \pm 0.10$ & $100.33^{\mathrm{f}} \pm 0.04 \mathrm{f}$ & $41.83^{c} \pm 0.02$ & $6.44^{\mathrm{c}} \pm 0.01$ \\
\hline & Central & $48.14^{\mathrm{a}} \pm 0.06$ & $82.63^{\mathrm{a}} \pm 0.05$ & $37.55^{\mathrm{a}} \pm 0.06$ & $6.36^{c} \pm 0.03$ \\
\hline \multirow{3}{*}{ Bulb } & Pickled & $55.78^{c} \pm 0.08$ & $93.75^{\mathrm{c}} \pm 0.11$ & $42.35^{\mathrm{d}} \pm 0.08$ & $6.01^{\mathrm{a}} \pm 0.05$ \\
\hline & Big & $62.08^{\mathrm{d}} \pm 0.07$ & $95.65^{\mathrm{d}} \pm 0.06$ & $43.55^{\mathrm{e}} \pm 0.07$ & $6.31^{c} \pm 0.03$ \\
\hline & Small & $63.78^{\mathrm{d}} \pm 0.15$ & $97.48^{\mathrm{e}} \pm 0.17$ & $42.91^{\mathrm{d}_{ \pm}} \pm 0.02$ & $6.16^{\mathrm{b}} \pm 0.02$ \\
\hline $\mathrm{F}$ & & 10421.38 & 5101.20 & 1737.23 & 52.39 \\
\hline Sig & & 0.000 & 0.000 & 0.000 & 0.000 \\
\hline
\end{tabular}

${ }^{\mathrm{a}-\mathrm{f}}$ Mean values with different superscript symbols along the columns are significantly $(\mathrm{P}<0.05)$ different. 
Table 4. Variation in macro elements among different tissues of Taşköprü garlic.

\begin{tabular}{cl|ccccc}
\hline \multirow{2}{*}{\multicolumn{2}{c|}{ Size }} & \multicolumn{5}{c}{ Macro element (ppm) } \\
\cline { 3 - 7 } Clove & Ca & K & P & S & Mg \\
& Big & $2648 \pm 10$ & $20430 \pm 30$ & $4065 \pm 6$ & $8067 \pm 7$ & $19.55 \pm 0$ \\
& Small & $3617 \pm 10$ & $21190 \pm 30$ & $5561 \pm 6$ & $9014 \pm 7$ & $144.7 \pm 4.9$ \\
& Central & $5883 \pm 14$ & $23740 \pm 30$ & $4701 \pm 6$ & $7293 \pm 6$ & $74.3 \pm 2.8$ \\
\hline \multirow{3}{*}{ Bulb } & Pickled & $6379 \pm 14$ & $21940 \pm 30$ & $7577 \pm 8$ & $12200 \pm 10$ & $504 \pm 12$ \\
& Big & $2998 \pm 9$ & $19440 \pm 20$ & $4962 \pm 6$ & $10100 \pm 10$ & $157.6 \pm 4.8$ \\
& Small & $11260 \pm 20$ & $18490 \pm 20$ & $4641 \pm 6$ & $6373 \pm 5$ & $33.78 \pm 0$ \\
\hline
\end{tabular}

Table 5 Variation in micro elements among different tissues of Taşköprü garlic.

\begin{tabular}{|c|c|c|c|c|c|c|c|c|c|c|c|c|}
\hline \multirow{2}{*}{\multicolumn{2}{|c|}{ Size }} & \multicolumn{11}{|c|}{ Micro element (ppm) } \\
\hline & & $\mathrm{Na}$ & $\mathrm{Mn}$ & \multicolumn{2}{|c|}{$\mathrm{Cl}$} & \multicolumn{2}{|c|}{$\mathrm{Si}$} & \multicolumn{2}{|c|}{$\mathrm{Al}$} & $\mathrm{Cu}$ & $\mathrm{Fe}$ & $\mathrm{Zn}$ \\
\hline \multirow{3}{*}{ Clove } & Big & $99.95 \pm 0$ & $25.9 \pm 0.3$ & 543.6 & & \multicolumn{2}{|c|}{$103.6 \pm 2.6$} & \multicolumn{2}{|c|}{$19.23 \pm 0$} & $9 \pm 0.3$ & $26.5 \pm 0.3$ & $32.2 \pm 0.3$ \\
\hline & Small & $100.76 \pm 0$ & $26.1 \pm 0.3$ & 575. & & \multicolumn{2}{|c|}{$156 \pm 2.6$} & \multicolumn{2}{|c|}{$154.8 \pm 2.2$} & $10.4 \pm 0.3$ & $28.9 \pm 0.4$ & $34 \pm 0.3$ \\
\hline & Central & $100.82 \pm 0$ & $29.1 \pm 0.3$ & 643.9 & & \multicolumn{2}{|c|}{$2007 \pm 6$} & \multicolumn{2}{|c|}{$5166 \pm 15$} & $8.5 \pm 0.3$ & $64.8 \pm 0.6$ & $37.8 \pm 0.3$ \\
\hline \multirow{3}{*}{ Bulb } & Pickled & $100.55 \pm 0$ & $38.1 \pm 0.3$ & 284.4 & & \multicolumn{2}{|c|}{$1326 \pm 5$} & \multicolumn{2}{|c|}{$392.2 \pm 4.4$} & $9.1 \pm 0.3$ & $377.7 \pm 1.7$ & $44.5 \pm 0.3$ \\
\hline & Big & $100.47 \pm 0$ & $30.6 \pm 0.3$ & 701 & & \multicolumn{2}{|c|}{$186.3 \pm 2.7$} & \multicolumn{2}{|c|}{$88.05 \pm 1.4$} & $9.2 \pm 0.3$ & $35.1 \pm 0.4$ & $33.3 \pm 0.3$ \\
\hline & Small & $100.34 \pm 0$ & $34.4 \pm 0.3$ & 818.7 & & \multicolumn{2}{|c|}{$1792 \pm 6$} & \multicolumn{2}{|c|}{$\begin{array}{l}88.00 \pm 1.4 \\
650.4 \pm 5.2\end{array}$} & $10.7 \pm 0.3$ & $267.6 \pm 1.4$ & $34.9 \pm 0.3$ \\
\hline \multirow{2}{*}{\multicolumn{2}{|c|}{ Size }} & \multicolumn{11}{|c|}{ Micro element (ppm) } \\
\hline & & $\mathrm{Ag}$ & & I & & $\mathrm{Sr}$ & & $\mathrm{e}$ & & $3 a$ & $\mathrm{Ti}$ & $\mathrm{Te}$ \\
\hline \multirow{3}{*}{ Clove } & Big & $7.5 \pm 0.6$ & \multicolumn{2}{|c|}{$7.9 \pm 0.7$} & \multicolumn{2}{|c|}{$11.9 \pm 0.1$} & \multicolumn{2}{|c|}{$0.3 \pm 0.1$} & \multicolumn{2}{|c|}{$44 \pm 3.9$} & $7.1 \pm 0.4$ & $16.8 \pm 0.8$ \\
\hline & Small & \multirow{2}{*}{$\begin{array}{l}5.5 \pm 0.6 \\
5.9 \pm 0.6\end{array}$} & \multicolumn{2}{|c|}{$6.2 \pm 0.8$} & \multicolumn{2}{|c|}{$16.3 \pm 0.1$} & \multicolumn{2}{|c|}{$0.45 \pm 0$} & \multicolumn{2}{|c|}{$1.87 \pm 0$} & $9.6 \pm 0.4$ & $11.6 \pm 0.7$ \\
\hline & Central & & \multicolumn{2}{|c|}{$7.5 \pm 0.8$} & \multicolumn{2}{|c|}{$16.5 \pm 0.1$} & \multicolumn{2}{|c|}{$0.47 \pm 0$} & & $2 \pm 0$ & $24.1 \pm 0.6$ & $10.3 \pm 0.6$ \\
\hline & Pickled & $8.1 \pm 0.6$ & & $3 \pm 0.9$ & & $2 \pm 0.1$ & & $8 \pm 0$ & 54. & $4 \pm 4.4$ & $31.4 \pm 0.8$ & $20.6 \pm 0.9$ \\
\hline Bulb & Big & $11 \pm 0.6$ & & \pm 0.8 & & $2 \pm 0.1$ & & $4 \pm 0$ & 56. & $3 \pm 4.6$ & $2.7 \pm 0.4$ & $29.1 \pm 1$ \\
\hline & Small & $6.7 \pm 0.6$ & & \pm 0.8 & 47 & $9 \pm 0.1$ & & $6 \pm 0$ & 58. & $3 \pm 4.4$ & $30.6 \pm 0.9$ & $14.7 \pm 0.8$ \\
\hline
\end{tabular}

Belhadj et al. (2015) found that the total phenolic content was $42.92 \pm 3.15 \mathrm{mg}$ in leaves, $32.31 \pm 2.3 \mathrm{mg}$ in bulbs and $22.2 \pm 3.81 \mathrm{mg}$ in roots. Queiroz et al. (2009) found that fried garlic content varied between 4.78 and $8.32 \mu \mathrm{g} / \mathrm{mg}$. and also it was lower than the fresh garlic samples (from 6.99 to $8.32 \mu \mathrm{g} / \mathrm{mg}$ ). Kim et al. (2013) expressed that the total phenolic acid content of a local garlic cultivar was $17.86 \mathrm{mg} / \mathrm{kg}$. Beato et al. (2011) showed that the amount of total phenolic ranged from $3.4 \mathrm{mg} / \mathrm{g}$ to $10.8 \mathrm{mg} / \mathrm{g}$ in different garlic cultivars. Nagella et al. (2014) measured phenolic profiles and screened antioxidant activities of some garlic bulbs collected from different locations of Korea. According to their results, the amount of total phenolic varied widely from the different locations and ranged from 33.50 to $49.89 \mathrm{mg}$.

Minerals are essential for optimal growth, development and maintenance of all living thing including plant and animal. They are categorized as macronutrients and micronutrients. In addition, they are nutritionally important components in food and enhance tolerance to many chronic and some infectious diseases (Elliot et al. 2008; Żurawik et al., 2013). It is reported that garlic is an important source of minerals (Turfan et al., 2016; Mardoni, 2017). The mineral profile as macro and micronutrients of the three cloves and bulbs of garlic in this present study are given in Table 4 and Table 5. It was seen from the Table 4 that mean potassium $(\mathrm{K})$ concentration in the garlic cloves and bulbs were highest compared to all the other elements. The central cloves showed the highest K content (23740 ppm), whereas the small bulb had the lowest concentration (18490 ppm).

Calcium (Ca) was the second highest element determined in the garlic samples and ranged from 2648 ppm to $11260 \mathrm{ppm}$. The highest amount of Ca (11260 ppm) was noted in the small bulb, whereas the lowest level (2648 ppm) was determined in the big cloves. The highest level for phosphorus $(\mathrm{P})$, sulfur $(\mathrm{S})$ and magnesium $(\mathrm{Mg})$ were found in the pickled bulb (7577 ppm, $12200 \mathrm{ppm}$ and 504 ppm, respectively) (Table 3). Whereas, the lowest $\mathrm{P}$ and $\mathrm{Mg}$ were seen in the big cloves (4065 ppm and $19.55 \mathrm{ppm}$ ), the lowest $\mathrm{S}$ was estimated in the big bulb (6373 ppm) (Table 4). The sodium (Na) level of the garlic samples was $99.95 \mathrm{ppm}$ for the big clove to $100.82 \mathrm{ppm}$ for the central clove (Table 5). Aluminum (Al) and silisyum (Si) contents were found to be highest (5166 ppm and $2007 \mathrm{ppm}$ respectively) in the central cloves, whereas they were lowest (19.23 ppm and $103.6 \mathrm{ppm}$ respectively) in the big cloves. Similarly, iron (Fe) and zinc ( $\mathrm{Zn})$ contents were lowest in the big cloves (26.5 ppm and $32.2 \mathrm{ppm}$ respectively), whereas they were highest in the pickled cloves (377.7 ppm and $44.5 \mathrm{ppm}$ respectively) (Table 4).

The concentrations of manganese $(\mathrm{Mn})$ in the different samples of garlic were $38.1 \mathrm{ppm}$ in the pickled, $34.4 \mathrm{ppm}$ in the big bulb as the highest value, and $25.9 \mathrm{ppm}$ in the big cloves as the lowest level. Chlorine $(\mathrm{Cl})$ content of garlic tissues varied between $284.4 \mathrm{ppm}$ for the pickled bulb to 818.7 ppm for the small bulb. Copper $(\mathrm{Cu})$ amount ranged from 8.5 ppm for the central clove to $10.7 \mathrm{ppm}$ for the small bulb, while iodine (I) varied from $6.2 \mathrm{ppm}$ for the small bulb to $25.3 \mathrm{ppm}$ for the pickled bulb (Table 5). According to element values, there was an important variation between the bulbs and the cloves. It was reported that elemental profile of garlic variations depended on cultivars, part of garlic as root, leaf and bulb (Azoom et al., 2014; Petropoulos et al., 2018). Khalid et al. (2014) determined that Allium tuberosum contained high contents of calcium $(28.66 \mathrm{mg} / 100 \mathrm{~g})$, potassium (10.62 $\mathrm{mg} / 100 \mathrm{~g})$ and zinc $(59.00 \mathrm{mg} / 100 \mathrm{~g})$. Khan et al. (2016) stated that the mineral analysis of garlic showed higher concentration of potassium (48.75) followed by calcium $(24.79 \mathrm{mg} / 100 \mathrm{~g})$. And also, as trace minerals were $\mathrm{Na}, \mathrm{Fe}, \mathrm{P}$, $\mathrm{Zn}, \mathrm{Cu}, \mathrm{Mn}$ and $\mathrm{Mg}$ with concentration of $4.06 \mathrm{mg} / 100 \mathrm{~g}, 3.93$, and $9.86,0.53,0.010,0.010$ and $2.63 \mathrm{mg} / 100 \mathrm{~g}$, respectively. 
According to Żurawik et al. (2013), the most abundant minerals in garlic were $\mathrm{Ca}\left(12.9 \mathrm{~g} \mathrm{~kg}^{-1}\right), \mathrm{K}\left(48.4 \mathrm{~g} \mathrm{~kg}^{-1}\right), \mathrm{Na}$ $\left(0.2 \mathrm{~g} \mathrm{~kg}^{-1}\right), \mathrm{P}\left(3.6 \mathrm{~g} \mathrm{~kg}^{-1}\right), \mathrm{Mg}\left(2.6 \mathrm{~g} \mathrm{~kg}^{-1}\right)$, and $\mathrm{S}\left(9.1 \mathrm{~g} \mathrm{~kg}^{-1}\right)$. Hacıseferoğulları et al. (2005), Akinwande and Olatunde (2015) and Petropoulos et al. (2018), found also similar result and they showed that $\mathrm{K}$ and $\mathrm{Ca}$ were the most abundant element in garlic samples. $\mathrm{Mg}, \mathrm{Na}$ and $\mathrm{Ca}$ were also detected in considerable amounts.

\section{Conclusion}

The results obtained from this study have indicated that there are significant differences $(\mathrm{P} \leq 0.05)$ in the element profile, some chemical constituents and growth parameters between the bulbs and the clove categories. According to the growth parameters, the highest values as the shoot and root length, the fresh and dry weight and also germination were obtained from the seedlings germinated from the big cloves. Based on the results from mean macro and micro element values, the big cloves contained the lowest $\mathrm{Mn}, \mathrm{Si}$, $\mathrm{Al}, \mathrm{Fe}, \mathrm{Zn}$ and $\mathrm{Sr}$ compared to other tissues. In addition, mean sodium content was similar for all samples of garlic. Selenium was found to be the lowest micronutrient in all parts of garlic. Mean content of proline and free amino acid was highest in the big cloves, whereas the small bulb had the lowest contents. Mean $\beta$-carotene level was higher in the small bulb of garlic, while the highest value of total phenolic content found in the big cloves of garlic.

\section{Acknowledgement}

This study has been carried out by virtue of the assistance provided through the of KUBAP-01 / 2014-21 project.

\section{References}

Agıć D, Bukvić G, Grljušıć S, Bešlo D, Horvatić J, Novoselović D. 2009. Effect of $\mathrm{pH}$ on $\alpha$-amylase activity and early seedling growth of red clover (Trifolium pratense L.). Not. Bot. Hort. Agrobot. Cluj, 37 (2): 77-80.

Akinwande BA, Olatunde SJ. 2015. Comparative evaluation of the mineral profile and other selected components of onion and garlic. International Food Research Journal, 22: 332-336.

Alıcı EH, Arabac1 G. 2016. Determination of SOD. POD. PPO and CAT enzyme activities in Rumex obtusifolius L. Annual Research \& Review in Biology, 11(3): 1-7.

Alves RE, Rufino MSM, Sampaio CG. 2008. Antioxidant activity measurement in tropical fruits: A case study with acerola. Acta Horticulturae, 773: 299-305.

Asdaq SM, Inamdar MN. 2010. Potential of garlic and its active constituent.S-allyl cysteine as antihypertensive and cardioprotective in presence of captopril. Phytomedicine, 17: 1016-1026.

Azoom AAA, Hamdi W, Zhanı K, Hannachi C. 2014. Evaluation of mineral element, sugars and proteins compositions in bulbs of eight onion (Allium cepa $\mathrm{L}$.) varieties cultivated in Tunisia. International Research Journal of Engineering and Technology, 2(4): 35-39.

Azzini E, Durazzo A, Foddai MS, Temperini O, Venneria E, Valentini S, Maiani, G. 2014. Phytochemicals content in Italian garlic bulb (Allium sativum L.) varieties. Journal of Food Research, 3(4): 26-32.

Bates LS, Waldern RP, Teare ID. 1973. Rapid determination of free proline for water-stress studies. Plant and Soil, 39: 205207.
Beato VM, Orgaz F, Mansilla F, Montan o A. 2011. Changes in phenolic compounds in garlic (Allium sativum L.) owing to the cultivar and location of growth. Plant Foods Hum. Nutr, 66(3): 218-223.

Belhadj F, Messaoud C, Hlel BT, Demirtas I, Marzouki MN. 2015. Phytochemical screening, antioxidant and antimicrobial activities of Allium sativum $L$. leaves, bulbs and roots. Identification of Major Active Compounds. International Journal of Pharmaceutical Research and BioScience, 4(5): 46-68.

Bernfeld P. 1991. Amylase $\alpha$ and $\beta$. Methods in Enzymology, 1: 149-151.

Bhandari P. 2012. Garlic (Allium sativum L.): A review of potential therapeutic applications. Int. J. Green Pharm, 6: 118-129.

Bradford MM. 1976. A rapid sensitive method for the quantitation of micro program quantities of protein utilizing the principle of protein-dye binding'. Anal Biochem, 72: 248254.

Cakmak I. 1994. Activity of ascorbate-dependent $\mathrm{H}_{2} \mathrm{O}_{2}$ scavenging enzymes and leaf chlorosis are enhanced in magnesium and potassium deficient leaves but not in phosphorus deficient leaves. Journal of Experimental Botany, 45 (9):1259-1266.

Carvalho ML, Pimentel AC, Fernandes B. 2005. Study of heavy metals in wild edible mushrooms under different pollution conditions by X-Ray Fluorescence Spectrometry. Analytical Sciences, 21(7): 747-750.

Castellanos JZ, Vargas-Tapia P, Ojodeagua JL, Hoyos G. 2004. Garlic productivity and profitability as affected by seed clove size. Hort Science, 39(6): 1272-127.

Castellanos JZ, Vargas-Tapia P, Ojodeagua JL, Hoyos G. 2004. Garlic productivity and profitability as affected by seed clove size, planting density and planting method. HortScience, 39: 1272-1277.

Caverzan A, Passai G, Rosa SB, Ribeiro CW, Lazzarotto F, Margis-Pinheiro M. 2012. Plant responses to stresses: role of ascorbate peroxidase in the antioxidant protection. Genet Mol Biol, 35(4): 1011-1019.

Chandra-Hioe MV, Rahman HH, Arcot J. 2017. Lutein and $\beta$ Carotene in selected Asian leafy vegetables. J Food Chem Nanotecho, 3(3): 93-97.

Chung LY. 2006. The antioxidant properties of garlic compounds: Allyl cysteine, alliin, allicin and allyl disulfide. J. Med. Food, 9: 205-213.

Ciereszko I. 2018. Regulatory roles of sugars in plant growth and development. Acta Soc Bot Pol, 87(2): 3583.

Circu ML, Aw TY. 2010. Reactive oxygen species. cellular redox systems. and apoptosis." Free Radical Biology and Medicine, 48 (6): 749-762.

Del Pozo A, Gonzalez MI. 2005. Developmental responses of garlic to temperature and photoperiod. Agric. Tecn, 65: 119126.

Elliot P, Kesteloot H, Appel LJ, Dyer AR, Ueshima H, Chan Q, Brown IJ, Zhao L, Stamler J. 2008. Dietary phosphorous and blood pressure International study of macro- and micronutrients and blood pressure. Hypertension, 51: 669-675.

Fiedor J, Burda K. 2014. Potential role of carotenoids as antioxidants in human health and disease Nutrients, 6: 466488.

Gilchrist M, Winyard, Ü.P.G. Benjamin N. 2010. Dietary Nitrategood or bad? Nitric Oxide, 22: 104-109.

Gupta V. 2003. Seed germination and dormancy breaking techniques for indigenous medicinal and aromatic plants. Journal of Medicinal and Aromatic Plants Science, 25: 402-407.

Haciseferogullari H, Ozcan M, Demir F, Calisir S. 2005. Some nutritional and technological properties of garlic (Allium sativum L.). J. Food Eng, 68: 463-469. 
Handel EV. 1968. Direct microdetermination of sucrose. Anal. Biochem, 22: 280-283.

Hanson P, Ray-Yu Y, Lien-chunget C, Ledesma L, Ledesma D. 2011. Carotenoids, ascorbic acid, minerals and total glucosinolates in choysum (Brassica rapa cvg. parachinensis) and kailaan (B. oleraceae Alboglabra group) as affected by variety and wet and dry season production. $J$ Food Comp Anal, 24(7): 950-962.

Hughes J, Collin HH, Tregova A, Tomsett AB, Cosstick R, Jones MG. 2006. Effect of low storage temperature on some of the flavour precursors in garlic (Allium sativum). Plant Foods Human Nutr, 61: 81-85.

Ipek M, Ipek A, Simon PW. 2008. Molecular characterization of Kastamonu garlic: An economically important garlic clone in Turkey. Scientia Horticulturae, 115(2): 203-208.

Jenderek MM, Zewdie Y. 2005. Within- and between-family variability for important bulb and plant traits among sexually derived progenies of garlic. HortScience, 40: 1234-1236.

Jones AM. 2014. Dietary Nitrate Supplementation and Exercise Performance Sports Med, 44 (1): 35-45.

Khalid N, Ahmed I, Latif MSZ, Rafique T, Fawad SS. 2014. Comparison of antimicrobial activity, phytochemical profile and minerals composition of garlic Allium sativum and Allium tuberosum. Journal of the Korean Society for Applied Biological Chemistry, 57(3): 311-317.

Khan MS, Quershi NA, Asghar S, Shakeel M. 2016. Analysis of minerals profile, phenolic compounds and potential of Garlic (Allium sativum) as antioxidant scavenging the free radicals. International Journal of Biosciences, 8(4): 72-82.

Kim JS, Kang OJ, Gweon OC. 2013. Comparison of phenolic acids and flavonoids in black garlic at different thermal processing steps. J Funct Foods, 5(1): 80-86.

Koruri SS, Banerjee D, Chowdhury R, Bhattacharya P. 2014. Studies on prebiotic food additive (inulin) in Indian dietary fibre sources-Garlic (Allium sativum), wheat (Triticum spp.), oat (Avena sativa) and dalia (Bulgur). Int. J. Pharm. Sci, 6: 278-282.

Kotagariwar VV, Choudhary MH, Damke MM, Jadho BJ. 1997. Effect of planting methods and clove size on growth, yield and quality of garlic (Allium sativum L) cv Godawari. PKV Research Journal, 21(2): 182-184.

Krishnamurthy PT, Bajaj J, Sharma A, Manimaran S, Ravanappa PKB, Pottekad V. 2010. Hepatoprotective activity of terpenoids and terpenoid fractions of Scoparia dulcis L. Oriental Pharmacy and Experimental Medicine, 10: 263-270.

Le Quere S, Lacan D, Lemaire B, Carillonand J, Schmitt K. 2014. The role of superoxide dismutase (SOD) in skin disorders. Nutrafoods, 13(1): 13-27.

Lisciani S, Gambelli L, Durazzo A, Marconi S, Camilli E, Rossetti C, Gabrielli P, Aguzzi A, Temperini O, Marletta L. 2017. Carbohydrates components of some Italian local landraces: Garlic (Allium sativum L.). Sustainability, 9(11): 1922-1927.

Liu RH. 2013. Health-promoting components of fruits and vegetables in the diet. Advances in Nutrition, 4(3):384-392.

Mardoni R. 2017. Determining the chemical compositions of garlic plant and its existing active element. Journal of Applied Chemistry, 10(1):63-66.

McCarty DR. 1995. Genetic control and integration of maturation and germination pathways in seed development. Ann. Rev. Plant Physiol. Plant Mol. Bio, 46: 71-93.

McCready R, Guggolz MJ, Silviera V, Owens HS. 1950. Determination of starch and amylase in vegetables. Anal. Chem, 22: 1156-1158.

Moore S, Stein WH. 1948. Photometric method for use in chromatography of amino acids. J. Biol. Chem, 176: 367-388.

Nagata M, Yamashita I. 1992. Simple method for simultaneous determination of chlorophyll and carotenoids in tomato fruit. Nippon Shokuhin Kogyo Gakkaish, 39: 925-928.
Nagella P, Thiruvengadam M, Ahmad A, Yoon JYA, Chun IM. 2014. composition of polyphenols and antioxidant activity of garlic bulbs collected from different locations of Korea. Asian Journal of Chemistry, 26(3): 897-902.

Nasir S, Regesa T, Yirgu M. 2017. influence of clove weight and planting depth on yield and yield components of Garlic (Allium sativum L.) Influence of Clove Weight and Planting Depth on Yield and Yield Components of Garlic (Allium sativum L.). AmEuras. J. Agric. \& Environ. Sci 17 (4): 315-319.

Petropoulos SA, Fernandes A, Ntatsi G, Petrotos K, Barros L, Ferreria ICFR. 2018. Nutritional Value. Chemical Characterization and Bulb Morphology of Greek Garlic Landraces. Molecules, 23(2): 319.

Qidwai W, Ashfaq T. 2013. Role of garlic usage in cardiovascular disease prevention: An evidence-based approach. Evid. Based Complement. Alternat. Med, 125649.

Ran P, Unni KM, Karthikeyan J. 2004. Evaluation of Antıxidant Properties of Berries. Indian Journal of Clinical Biochemistry, 19 (2): 103-111.

Rein D, Paglieroni TG, Pearson DA, Wun T, Schmitz HH, Gosselin R, Keen CL. 2000. Cocoa and wine polyphenols modulate platelet activation and function. Journal Nutrient, 130 (8): 2120-2126.

Rekowska E, Skupie'n K. 2009. The influence of selected agronomic practices on the yield and chemical composition of winter garlic. Veg. Crop Res. Bull., 70: 173-182.

Ritota M, Casciani L, Han BZ, Cozzolino S, Leita L, Sequi P, Valentini M. 2012. Traceability of Italian garlic (Allium sativum L.) by means of HRMAS-NMR spectroscopy and multivariate data analysis. Food Chemistry, 135: 684-693.

Sharma R. 2014. Polyphenols in health and disease: practice and mechanisms of benefits. Polyphenols in human health and disease. Academic. San Diego, 757-78.

Singleton VL, Orthofer R, Lamuela-Raventos RM. 1999. Analysis of total phenols and other oxidation substrates and antioxidants by means of Folin-Ciocalteu reagent. Methods Enzymol, 299:152-178.

Stajner D, Canadanovic-Brunet J, Pavlovic A. 2004. Allium schoenoprasum L., as a natural antioxidant. Phytoter. Res. 18 (7): 522-524.

Story EN, Kopec RE, Schwartz SJ, Harris GK. 2010. An Update on the Health Effects of Tomato Lycopene. Annu Rev Food Sci Technol, 1 (1):189-210.

Sudıpta KM, Swamy KM, Balasubramanya S, Anuradha M. 2014. Assessment of Genetic Fidelity. Antioxidant Enzyme Activity and Proline Content of Micropropagated and Field Grown Plants of Leptadenia Retıculata (Wight \& Arn.)- An Endangered Medicinal Plant. Plant Cell Biotechnology and Molecular Biology 15(3\&4):127-135

Tuan PA, Kim JK, Kim HH, Lee SY, Park NI, Park SU. 2011. Carotenoid accumulation and characterization of cdnas encoding phytoene synthase and phytoene desaturase in garlic (Allium sativum). J. Agric. Food Chem, 59: 5412-5417.

TUIK (Turkish Statistical Institute) Statistical Data. (web page: http://www.tu1k.org.tr. accessed on (20.12.2017).

Turfan N, Kurnaz A, Alay M, Sariyıldız T. 2016. Determining of Some Chemical Properties in Taşköprü Gralic Stored in Different Conditions. Kastamonu Univ., Journal of Forestry Faculty, 16 (2):427-437.

Vural H, Eşiyok D, Duman İ. 2000. Cultured Vegetables (Vegetable Cultivation). Ege University Publication, Izmir.

Zahra S, Amin B, Mehdi Y. 2010. The salicylic acid effect on the tomato (Lycopersicum esculentum Mill.) germination, growth and photosynthetic pigment under salinity stress $(\mathrm{NaCl})$. Journal of Stress Physiology and Biochemistry, 6(3): 4-16.

Żurawik A, Jadczak D, Żurawik P. 2013. Content of macro- and microelements in the yield of garlic chives (Allium tuberosum Rottler ex Spreng.) according to the plant age. J. Elem, 18(3), 521-528. 